\title{
Indonesia's Digital Diplomacy: Problems and Challenges
}

\author{
Ludiro Madu \\ International Relations Department \\ Universitas Pembangunan Nasional 'Veteran' Yogyakarta \\ JI. SWK 104, Condongcatur, Sleman, Daerah Istimewa Yogyakarta 55283 \\ ludiro@gmail.com \\ Submitted: J une 28, 2018; accepted: September 20, 2018
}

\begin{abstract}
Abstrak
Tulisan ini menjelaskan perkembangan terbaru diplomasi digital yang dijalankan Kementerian Luar Negeri Indonesia dalam merespon tingginya tantangan teknologi, informasi, dan komunikasi (TIK) terhadap kepentingan nasional Indonesia. Penggunaan internet dan sosial media telah mengubah praktik diplomasi berbagai negara. Menganalisis saling keterkaitan antara internet dan diplomasi, tulisan ini ingin melihat jalan yang ditempuh Kemenlu dan diplomatnya untuk mengikuti arus perkembangan TIK dan menggunakannya sebagai alat penarik simpati masyarakat. Jika ditelisik kembali, kebijakan diplomasi digital Kemenlu dan implementasinya melalui situs web dan perangkat sosial media lain, memperlihatkan komitmen yang kuat dalam penggunaan diplomasi digital untuk mengatur segala urusan luar negeri di era daring. Diplomasi digital telah memperlihatkan berbagai keuntungan seperti komunikasi langsung dan interaktif dengan pihak asing. M eski demikian, diplomasi digital Indonesia harus menghadapi berbagai permasalahan yang erat kaitannya dengan penggunaan internet oleh aktor negara dan non-negara, baik dalam maupun luar negeri, yang mungkin hal tersebut memiliki risiko bagi hubungan antarnegara. Tulisan ini berargumen bahwa peningkatan penggunaan diplomasi digital akan menentukan kapabilitas Kemenlu dan diplomatnya dalam menghadapi masalah dan tantangan hubungan internasional di era internet.
\end{abstract}

Kata kunci: Indonesia, Kementerian Luar Negeri, diplomasi digital, Digital Command Center, Badan Siber dan Sandi Negara.

\begin{abstract}
This paper explains the recent development of Indonesia's digital diplomacy-which Indonesia's Ministry of Foreign Affairs (M OFA) has conducted-in responding to the growing challenges of information, communication, and technology (ICT) towards its national interest. The use of the internet and its social media has definitely changed the practices of diplomacy among sovereign states, including Indonesia. Analyzing the issue within the interplay between internet and diplomacy, this paper looks at the way Indonesia's MOFA and its diplomats have kept up with the rapid development of the ICT by mastering the use of internet in winning people's hearts and minds. Tracing back the MOFA's policies and implementations of digital diplomacy through its website and other platforms of social media reveals its strong commitment in using digital diplomacy in managing its foreign relations in the recent internet era. Digital diplomacy has presented several benefits for having a direct and interactive communication with foreign audiences. In addition, Indonesia's digital diplomacy had also to deal with various problems which are closely related to the increasing use of internet among states and non-state actors-both in domestic and international levels-which may put risk to state-to-state relations. Therefore, this paper argues that the response of Indonesia's M OFA and its diplomats towards the increasing use of digital diplomacy would determine its capability in managing various problems and challenges of international relations in the recent internet era.

Keywords: Indonesia, Ministry of Foreign Affairs (MOFA), digital diplomacy, Digital Command Center, the National Cyber and Encryption Agency.
\end{abstract}

\section{INTRODUCTION}

Digital diplomacy has increasingly been a hot topic in modern foreign policy, particularly in public diplomacy (M adu, 2017b). A Imost all embassies have interestingly used social media as an interactive and convenient tool for promoting their countries, informing people about their lat-

est activities and engaging with their followers, both their own citizen and others in foreign countries. $M$ any embassies account can be found on Facebook, Twitter, Line, Instagram, or YouTube. The use of the internet for diplomacy purposes has changed the way of foreign embassies 
engaged with local audiences in other countries. YingJing (2017) pointed out that "social media is an effective way for embassies to communicate to target groups, more so than conventional (offline or traditional) public diplomacy."

The case of Indonesia shows that digital diplomacy has been a serious challenge for recent practices of its diplomacy in the era of President Joko W idodo. Although the idea of using social media for diplomacy can be traced back in early 2000s since its first usage of website, the Jokowi's government is the first that officially declared its importance through the Ministry of Foreign Affairs (M OFA) in 2016. The M OFA enthusiastically welcomed the recent development on the digital diplomacy by asserting the importance of internet for assisting the work of diplomats without any delay (M ovanita, 2016). In responding to this development, Indonesia's MOFA encouraged its diplomats to keep up with the rapid development of information communication and technology (ICT) tools by exploring the use of new media in various training programs, both in domestic and international levels (Yosephine, 2016).

This paper seeks to understand the evolving ways in which Indonesia's diplomacy has used ICT tools to engage, coordinate, and influence one another in managing the country's national interest in this internet era. It explains the problems that Indonesia's diplomacy has to deal with the increasing use of theinternet. This paper applies descriptive qualitative research method by analyzing the way Indonesia, especially the M OFA, in responding to the growth of internet usein digital diplomacy. The case study is important for understanding to what extent the M OFA has thought of the issue seriously.

\section{ANALYSIS}

\section{INTERNET AND DIPLOMACY}

In recent digital era, states articulate their identity and foreign policy interests of the struggle for online power. Different from traditional power which is physical or tangible in nature, the online power is closely related to soft power. States use the internet to seek influences over the perceptions and creating a favorable architecture for promoting their national interests. There have been many debates on the nexus between internet and diplomacy which led to unconcluded debates on the term of 'cyber diplomacy, ' 'internet diplomacy,' 'digital diplomacy,' and 'e-diplomacy' (DiploFoundation, 2015). While foreign ministries throughout the world have been eager to adopt 'digital diplomacy,' each ministry defines and practices this form of diplomacy in a different manner. This paper also uses theterm of digital diplomacy as 'solving foreign policy problems using the Internet' (C opeland, 2015).

Digital diplomacy has played significant rolefor today's foreign policy, including the role and influence of the internet and new technologies on the objectives, tools and structures of diplomacy. Early literatures on digital diplomacy can be traced back to Brian H ocking's D iplomacy in the D igital A ge (2015) and Kamen Lovez's The D igital D iplomacy Potential (2013). Both literatures interestingly point out two different tendencies on the linkage between internet and diplomacy. Somescholars believe that digitalization enhances public diplomacy, while others claim that it completely alters it into something new, known as digital diplomacy. In cyber space, both state and non-state actors inevitably struggle for influence and power (Potter, 2002). Therefore, following Hocking and Lovez, digital diplomacy is supplement to traditional diplomacy that can help a country in order to advance its foreign policy goals, extend international reach, and influence people in any other side of the world by using internet or other digital instruments to conduct relation between states or other international entities.

W ithin this context, digital diplomacy promotes the use of ICT to fulfil the state's foreign policy goals by winning hearts and minds of society, both in home country and others. Instead of substituting, diplomacy has more to do with complementing traditional diplomacy. In the era of digital diplomacy, governments or non-state actors have objectives they want in order to secure and develop. W ilson P. Dizard (2001) revealed three important roles that diplomacy can play in this information era. The first is the increasing issues of foreign policies which involve and use ICT tools. In the U nited States (U S), the increasinguse of ICT tools has indirectly resulted from new policies which were discussed in various online fora. Additionally, ICT tools have also taken important role of chang- 
ing geopolitical interests of the U S. Second, various changes in the arrangement of information sources in the M OFA and its related bureaus on the issue of foreign policy. Third, increasing role of public diplomacy, particularly in using ICT for building public opinion on foreign policy matters. These roles have inevitably promoted the importance of overt than covert practices of diplomacy in many countries, including Indonesia. The last role asserts the close connection between public and digital diplomacy in foreign policy of a country.

In addition, Ben Scot-an innovation advisor to former Secretary of State of the U S, H illary C linton-outlines three important components of digital diplomacy: 1) Public diplomacy, including the use of online platforms; 2) Building expertise in technology policy and understanding the way the internet impacts international developments such as political movements; 3) Impact on development policy and how ICT can be used more effectively to promote economic growth (C ave, 2015). The internet has undoubtedly also managed to democratize diplomacy by enhancing access of diplomacy to both state and non-state actors in order to express their aspiration. Therefore, the internet does not merely give impact to liberalize domestic politics, but it also unprecedentedly influences the practice of diplomacy among countries.

A nother benefit of using the internet for diplomacy is the easiness of doing diplomacy without having to be at the same place physically. Interestingly, this online representation has similar role with the type of physical diplomatic representation. $U$ sing an example on the case of U S' V irtual Embassy in Tehran (Iran)-which waslaunched in December 2011-M anor (2016) portrayed the extent to which the U S used its website to help them interact with I ranian citizens online. Although both countries do not have any diplomatic relations, digital diplomacy has enabled different actors of both countries to develop their relations without the support of any physical diplomatic representation.

Digital diplomacy allows countries to project their soft power beyond their borders. It is now becoming commonplace for politicians and their staffers to use platforms like T witter or Facebook to serve their own political purposes as well as those of their nation. O $n$ T witter, for instance, it increasingly develops into type of networking known as 'twiplomacy' which refers to the way in which people in the modern world establish their relationships simply by 'following' each other on Twitter (Verrekia, 2017). Increasingly, world leaders and their representatives are employinge-diplomacy as a tool of communication, such as former U S President Barack O bama and others. Former President of Indonesia, Susilo Bambang Yudhoyono, has proven incredibly adept at the usage of ICT for mobilizing people's support when several Indonesia's high-ranking figures were tapped by Australian Intelligent Service. Social media usage, however, is not becoming a replacement for traditional diplomatic action (Antony, 2014). In times of bilateral or international crisis, countries are usually recommended to use traditional diplomacy, instead of digital diplomacy.

\section{INDONESIA'S DIGITAL DIPLOMACY}

Almost all diplomatic representatives have developed their official website accounts and other online presenceincluding Facebook and I nstagram accounts-for representing their national interests. Following world leaders, a growing number of ambassadors and diplomats have an active Twitter and other social media accounts. The Indonesia's MOFA indeed had realized the significant role of ICT in diplomacy since the early 2000s. As part of its organizational reform, theM OFA established the D irectorate $G$ eneral of Information and Public Diplomacy in 2002. The presence of this new directorate general significantly indicated fundamental and strategic policy on the way Indonesia's MOFA would conduct public diplomacy in the future. Therefore, the online presence of Indonesia's MOFA reflects Indonesia's strong commitment on the use of ICT for implementing its foreign policy in recent digital era.

For Indonesia, awareness of digital diplomacy has increasingly been positive since 2017. In early 2017, M inister of Foreign Affairs, Retno Marsudi, pointed out strategic importance a Digital Command Center (DCC) for supporting and facilitating the use of digital diplomacy at the A nnual Speech of M inister of Foreign Affairs 2017 (Kemlu RI, 2017). The statement was followed by the establishment of a Digital Command Center (DCC) as a crisis management center at M OFA (LPSE Kemlu RI, 2017). In 
addition, it also has function of a 'watch and monitor' and analyzes the trend of domestic and international public response towards Indonesia's foreign policy. Within the Directorate of Information and M edia of Directorate General of Information and Public Diplomacy, DCC serves as a coordination center between the M OFA and Indonesia's representative offices in foreign countries in response to crisis or emergency situations requiring immediate treatment, such as natural disasters, armed conflict, and the protection of Indonesian citizens. These functions seemingly symbolize the presence of thel ndonesia's state ('negara hadir') for its Indonesia's citizen as a reflection of its nationalistic behavior of recent foreign policies (M adu, 2017a).

In addition, the Indonesian missions abroad and all stakeholders in Indonesia should develop a national strategy which synergize and coordinate Indonesia's public diplomacy under the DCC . Currently, Indonesia has diplomatic relations with 190 countries in the world through 132 representatives in 96 countries, which are divided into 24 time-zones. Thus, the MOFA is actually working 24 hours a day, seven days a week. The Directorate for Information and $M$ edia Services and the Directorate for Public Diplomacy are the key units in digital and public diplomacy at the Indonesia's M O FA. Recent development also shows that almost all Indonesia's embassies havetheir own social media accounts, for instance Twitter and Facebook. In basic level, those online accounts serve at least as their online representation of Indonesia's national interest in foreign countries.

Compared to other foreign ministries all over the world, Indonesia's M OFA ranked 37th in 2016 on the issue of digital diplomacy (Digital Diplomacy Review 2017, 2017). Based on Twiplomacy ranking, the twitter account of the MOFA took the fourth position as the most reliable government account. ${ }^{1}$ The M O FA is trying to keep abreast of the utilization of information and communication technology to support Indonesian diplomacy. In 1996, the official website of the M OFA was launched, which later developed in 2008 and entered version 2.0 in 2016. Social media as a means of communication and information dissemination has been well utilized by the ministry since 2010. Compared to other foreign ministries in some other countries, however, the use of social media as tool of di- plomacy by the Indonesian MOFA is still moderate. Indonesia's MOFA claims to have better website rather than others (cf. www.kemlu.go.id).

Through digital instruments and social media, presidents, governments, and diplomats can simply bypass the old hierarchy of traditional diplomacy. Audiences can be directly closer to their leaders, while vlogs fundamentally change the paradigm of traditional diplomacy in terms of discretion and secrecy. U ntil 2018, the M OFA has managed the account on Facebook Page and Twitter (@Portal_Kemlu_RI). Since 0 ctober 2016, the M O FA has also managed instagram account (@kemlu_ri) with thousands or even hundreds of thousands of followers. Furthermore, the MOFA has also used the audiovisual platform as a means for disseminating information in the form of Foreign M inistry TV (Kemlu TV), which can beaccessed through the website of MOFA (www.kemlu.go.id). Until the writing of this paper, the Indonesia's MOFA has a twitter account (@portal_kemlu_RI) with over 130.000 followers, a facebook account (51.690 likes), and an instagram account (52.800 followers). In January 2017, the Indonesian Foreign M inister also announced new initiatives, namely a beta version of a mobile application called Safe Travel for Indonesian citizen travelling abroad.

In this regard, the development of synergy through digital media based on information and communication technology is a necessity. In her opening speech at the Kompasianival event in South Jakarta on Saturday, August 10, Retno said technology, amazing teamwork, and officials' responsibility are keys to solving diplomacy problems. Diplomats need to adjust the way they work and adapt to the current demands of the digital era, which involves diplomacy on social media (H alim, 2016). In various levels of diplomatic training, Indonesia's MOFA equipped its diplomats with various knowledge of recent development of cyberspace, especially on its benefits and challenges that Indonesia's government has to cope with (Kemlu RI, 2016). Therefore, thereis no doubt on thewellprepared diplomats and MOFA that Indonesia has in its way of responding to rapid development of the use of ICT in the struggle of power among nations in the recent digital era.

WINNING PEOPLE'S HEARTS AND MINDS 
M orethan just politicians and diplomats using Twitter and Facebook, digital diplomacyallows countries to project their power beyond their borders (Funnell, 2014). Physical border does not limit state's power anymore in digital era. Indonesia's Foreign M inister Retno Marsudi warns her diplomats "they cannot hidein the digital era and need to adjust the way they work-including by focusing on better open-source reporting-in order to represent Indonesia abroad" (C ave, 2016). Indonesia was the world's fourth most populous nation and its citizens have taken to social media in general and Twitter in particular. W ith such enthusiasm that less than a year ago Jakarta was named the number one Twitter city in the world, with Indonesians generating more tweets than people from any other country (Raeburn, 2013).

For Indonesia, digital diplomacy has given much benefit, such as a tool for diplomats to obtain timely information and to represent Indonesia abroad. It closely links to speed, accuracy, and honesty. Digital diplomacy together with amazing teamwork and officials' responsibilityarekeys to solving diplomacy problems. M inister Retno Marsudi asserts that,

"If Indonesian diplomats can provide real-time reports [on urgent matters such as natural disasters and hostage situations], we [in Jakarta] can immediately analyze what is going on. In performing their duties, the speed of information is a must for every diplomat. The citizen's trust could decrease if information from the government is not valid. We can't hidein this digital era; that's why honesty is important to tell the public what's really going on" (H alim, 2016).

Nevertheless, Indonesia's digital diplomacy also presents various unprecedented threats which are closely linked with national sovereignty in domestic level and the main aims of public diplomacy i.e. winning hearts and minds of foreign citizens in their own countries. First, online campaign for separatism. After the independence of Timor Leste and peace accord between Indonesia and the Free A ceh M ovement (G erakan A ceh M erdeka/ GAM), Indonesia has actively encountered with online separatism activities of the Free Papua 0 rganization ( 0 rganisasi Papua M erdeka/ O PM ). The O PM has taken much advantages of the internet's rapid development (Titifanue et al., 2016). In response to the OPM, President Joko W idodo has struggled to develop Papua under political jargon of 'Papua Land of Peace' (Papua Tanah Damai), but online maneuvers of Papuan activism through social media and other digital networks has significantly discredited achieve ments of Indonesia's government in developinginfrastructure in Papua.

Second, practices of cyberterrorism (Conway, 2004) have recently risen in the post-terrorist attack in Surabaya 2018 and MH Thamrin street, Jakarta, on January 2016. This phenomenon reveals the emergence of suicide bombers as new generation of terrorists who are skillful of using internet and information networks. They learned radical doctrines and manuals on bomb-making directly from the internet (Hui, 2010). Freedom of access and borderless information has forced government to take serious action on filtering and closing down many radical websites which potentially put risks on Indonesia's society.

Third, cyber (political) activism. The internet also enables public to take part in giving necessary feedback to foreign policy makers. Public opinion in the forms of news web, academician oped/opinion in daily and personal opinion in blog account or Twitter in a form of citizen journalism (Lim, 2003). Digital media provides a tool for contributing analysis on international issues, which closely related to Indonesia's national interest. In turn, public become active participant for diplomatic activism with the possibility of influencing the implementation of foreign policy.

Fourth, phenomenon of cyberwar among state actors (Arquilla \& Ronfeldt, 1993). The case of cyberwar-in the form of deface to websites belong to other country-occurred between Indonesia and M alaysia on their conflictual claim over A mbalat maritime territory (M adu, 2008). The case of A mbalat shows that cyberwar between both countries can easily be created from misunderstanding among their citizens. Therefore, the role of DCC of thel ndonesia's MOFA is inevitable in building coordination among divisions within the MOFA and further coordination among ministries in the government, especially under auspices of the National Cyber and Encryption A gency (Badan Siber dan Sandi $\mathrm{N}$ asional/ BSSN) which was established in early 2018 (Parameswaran, 2018).

All of thosethreats clearlyshow that the rapid progress 
of ICT has demanded an adaptive attitude to innovations in politics and diplomacy among nations. Regarding their scope, those threats certainly targeted the interest of Indonesia's government rather than its diplomatic relations. Larger scope of threats requires responsive policy at the national level which Indonesia's government recently responded by the establishment of the BSSN rather than the DCC of Indonesia's MOFA. Increasing awareness among government officials are of importance, but public participation has also become an important indicator of public diplomacy in digital era. Diplomacy is not merelya club of diplomats, but an arena of networking between state and non-state actors (H eine, 2013). Diplomatic negotiations have provided interactiveopportunities between citizens and governmental representatives had increased engagement among the public, who are becoming active designers and communicators of digital diplomacy (Yosephine, 2016).

\section{CHALLENGES AHEAD}

The use of new interactive communication technologies, such as the internet, W hatsA pp, Twitter, Facebook, Instagram, video sharing website, blogs and other social media networks, has made digital diplomacy becomes an active diplomatic modein international relations. Although Indonesia has gradually real ized the pivotal role of internet diplomacy and recently put it into practice, it is still lagging far behind. A part from these problems, Indonesia's digital diplomacy has to cope with potential danger of cyberattacks and others. This problem has been a growing concern for Indonesia's digital diplomacy, with particular reference to its urgency towards Indonesia's foreign relations.

By adopting digital diplomacy, Indonesia's M O FA realized that digital tools created new opportunities and challenges that diplomacy had to respond with. This meant that diplomatic institutions had to master the use of digital tools. The M OFA established digital infrastructure i.e. Digital Command C enter (DCC). The Ministry now has al ready established a DCC as a crisis management center. It also serves as a 'watch and monitor' and analyzes the trend of open source sources. DC C also serves as a coordination center between the MOFA and the Representative in response to crisis/ emergency situations requiring immediate treatment, such as natural disasters, armed conflict and the protection of Indonesian citizens.

Considering the developments described above, Indonesia should prepare several strategic options for dealing with challenges of digital diplomacy. First, Indonesia should empower its current digital infrastructure under coordination of BSSN. The MOFA'S DCC is included within the BSSN with specific duty on those of closely related to Indonesia's cyber security and digital diplomacy. Finding the proper mechanism for coordination across various ministries, agencies, and sub-national governments is of importance for recent Indonesia's condition with the increasing use of internet for everyday life.

Second, the Ministry should empower its digital command center to ensure that a speedy and well-equipped and coordinated process with related line ministries is in place, especially when facing emergency issues or crisis. This option will ensure that Indonesia collect and analyze data to define its correct or actionable policies toward certain issues. Building a digital command center, however, will require changes on culture and workflow processes within the M inistry and in relation with other line ministries/ agencies. Indonesia could take best lessons from other countries, such as the US, U nited Kingdom (UK), and Sweden which has applied diverse and comprehensivedigital policy and infrastructure for their domestic and international interests (Prabandari \& Rahyaputra, 2018).

Third, the MOFA should enhance its continuous training programs for its officials on media engagement and outreach. This program should involve stakeholders from local and international media for building further networking between media and diplomats. This training would ensure the increased capacities and networks of their diplomats to respond in proper manner with the challenging issue of social media platforms. O ne of the important issues is ethical arrangement of diplomats in uploading sensitive information in their individual social media accounts. This issuewould immediately raise dilemma between overt and covert diplomacy which refers to prolong debate between traditional and modern diplomacy. Recent development of public diplomacy inevitably demands transparency of diplomatic activities, but this personal activity 
should not risk national interest of a nation, including Indonesia.

Fourth, the Indonesia's M OFA should reconsider the ways it prepares and coordinates reliable and updated information through its website and other social media (Madu, 2017b). Establishment of such a digital command centre within M OFA is of importance for those coordinative and integrative tasks. D ifferent from other ministries, MOFA has to design, organize, and coordinate through its internal ad hoc agency for integrating websites of Indonesia's 131 missions abroad. W ith the presence of at least 131 websites, MOFA must formulate such a guide book which contains standards, norms, guidelines, criteria, and procedures in conducting digital public diplomacy. These challenges also apply to the increasing number of Indonesia's missions which have twitter accounts. There is no doubt that the number of twitter account would add up with the consideration of divisions within the Indonesia's M OFA.

Although Indonesia's government established the BSSN and the MOFA built the DCC, Indonesia has not produced a clear policy or blueprint for digital diplomacy. Moreover, Indonesia must improve its infrastructure, particularly information and communication technology. More importantly, the government should encourage the use of digital platforms among its diplomats through training. Indonesia also needs to update content continuously on its digital platforms. From its three Foreign Affairs Ministry twitter accounts, only KEMLU RI is updated continuously. Indonesia should consider appointinga special division to manage its digital activities. H aving a specific spokesperson dealing with digital activities is one strategic example for pursuing national interest in recent digital era.

\section{CONCLUSION}

Closelink between the internet and diplomacy has risen up the important of digital diplomacy, including in Indonesia. The practice of diplomacy has made foreign policy accessible for public participation through various ICT tools. Foreign ministries, embassies, and ambassadors (including diplomats) have expressed their increasing interest for reporting their diplomatic activities publicly.
Indonesia's M OFA has conducted various policies for coping with issues of digital diplomacy. Rather than just a matter of providing information to wider public through various social media accounts, M O FA's readiness has significantly reflected the Jokowi's government policy for having state's presence (negara hadir) for Indonesia's society, both domestically and internationally in recent cyber era. $\mathrm{H}$ aving the DCC in supporting its digital diplomacy, Indonesia's MOFA has to work hard for having institutional cooperation with other ministries with particular attention to find out strategies in dealing with the increasing cyber activism-including cyber terrorism. Further policy for building national strategy of digital diplomacy is necessary for Indonesia's government in order to cope with the increasing use of social media for interactive means between societies among different nations.

\section{ENDNOTES}

1 In addition to the use of website, Twitter has also been considered as one of the most influential social media platforms which foreign ministries used in selected countries. The US Department of State has ten twitter accounts in ten different non-English languages namely Arabic, Mandarin, Urdu, Hindi, Persian, Spain, Portuguese, Russian, French, and Turkey. With those twitter accounts, the US Department of States has disseminated information in a more effective way as the contents are presented in the audiences' respective language (Bjola \& Holmes, 2015).

\section{REFERENCES}

Anonymous. (2014). What Is Digital Diplomacy? From https:// envoycentre.wordpress.com/ 2014/01/22/what-is-digitaldiplomacy/ retrieved October 1, 2016.

Anonymous. (2015). Digital Diplomacy Week for Indonesian Senior Diplomat. From http://www.kemlu.go.id/en/berita/siaran-pers/ Pages/Digital-Diplomacy-Week-for-Indonesian-SeniorDiplomats.aspx. retrieved October 1, 2016.

Anonymous. (2017). Pengumuman Pengadaan Perangkat dalam Rangka Pembangunan Digital Command Center Tahap II, KEM ENLU TA 2017. From LPSE Kementerian Luar Negeri http:// Ipse.kemlu. go.id/eproc4/pengumuman/1106136 retrieved July $1,2017$.

Anonymous. (2016). Diplomats and Diplomacy. From https:// www.kemlu.go.id/id/berita/Pages/ Diplomat-dan-DigitalDiplomacy.aspx.

Arquilla, J. \& Ronfeldt, D. (1993). Cyberwar Is Coming. Comparative Strategy. Vol. 12, pp. 141-165.

Bjola, C. \& Holmes, M. (2015). Digital Diplomacy: Theory and Practice. New York: Routledge.

Cave, D. (2015). Does Australia do digital diplomacy? The Inter- 
preter. From http://www. lowyinterpreter.org/post/2015/04/17/ Does-Australia-do-digital-diplomacy. aspx retrieved October 5 , 2016.

(2016). Digital Diplomacy Links: The Spy Who 'Liked' Me, Cyber Influencing, ISIS, Indonesia and more. From https:// www.lowyinstitute.org/the-interpreter/digital-diplomacy-linksspy-who-liked-me-cyber-influencing-isis-indonesia-and-more retrieved October 5, 2016.

Conway, M. (2004). Cyber Terrorism: Media Myth or Clear and Present Danger? From http://doras.dcu.ie/505/1/ media_myth_2004.pdf.

Cooper, A. F., Heine, J., \& Thakur, R. (2013). The Oxford Handbook of Modern Diplomacy. UK: Oxford University Press, pp. 453472.

Copeland, D. (2015). Digital Technology. In A. F. Cooper, J. Heine, \& R. Thakur (eds.), The Oxford handbook of modern diplomacy. Oxford: OUP.

DiploFoundation. (2015). 'Digital Diplomacy, E-diplomacy, Cyber diplomacy.' From https://www.diplomacy.edu/e- diplomacy.

Dizard, W. P. (2001). Digital Diplomacy: US Foreign Policy in the Information Age. Washington DC.: Praeger Publisher.

Effendi, A. (2016). Teknologi Informasi Pengaruhi Kehidupan M asyarakat Indonesia. From http://www. pikiran-rakyat.com/ pendidikan/2016/04/23/teknologi-informasi-pengaruhikehidupan-masyarakat-indonesia-367467 retrieved October 2, 2016.

Funnell, A. (2014, March 25). E-diplomacy Goes Global. From http://www.abc.net.au/ radionational/programs/futuretense/ digital-diplomacy/5344156.

Halim, D. (2016). Digital Diplomacy a New Way to Solve Problems: Foreign M inister. From https://jakartaglobe.id/news/digitaldiplomacy-new-way-solve-problems-foreign-minister/ retrieved September 25, 2018.

Hocking, B. \& M elissen, J. (2015). Diplomacy in the Digital Age. The Netherlands: Netherlands Institute of International Relations Clingendael.

Hui, J. Y. (2010). The Internet in Indonesia: Development and Impact of Radical Websites. Journal of Studies in Conflict \& Terrorism, Vol. 33, Issue 2.

Jing, Y. (2017). Social Media and E-Diplomacy: Scanning Embassies on Weibo. From https:// www. whatsonweibo.com/digitaldiplomacy-foreign-embassies-unpopular-weibo/ retrieved May 1, 2018.

Lim, M. (2003). The Internet, Social Networks, and Reform in Indonesia. In N. Coultry, \& J. Curran (Eds.), Contesting Media Power: Alternative Media in a Networked World, 273-288. (Critical media studies). Lanham, MD [etc.]: Rowman \& Littlefield.

Lovez, K. \& M urray, A. (2013). 'The Digital Diplomacy Potential.' KMWorld 22(6).

Madu, L. (2008). Ambalat Netwar between Indonesia-Malaysia, 2005: Theoretical Reflection on International Relations in Internet Era (Ambalat Netwar antara Indonesia-M alaysia, 2005: Refleksi Teoritis mengenai Hubungan Internasional di Era Internet). Journal Global \& Strategis, Vol II, No. 1, January-June 2008, pp. 1-22.
Madu et al. (2017a). Indonesia's Foreign Policy under President Jokowi: More Domestic and Nationalist Orientations. International Journal of Scientific Research in Science and Technology. (3)2, pp. 189-197.

Madu et al. (2017b). Indonesia's Public Diplomacy in the Internet Era: Bringing the State Back. Dialogo Journal (4)1: 37 - 42.

Manor, I. (2018). How to Re-integrate \#Digital into Diplomacy. From https://digdipblog.com/2018/02/26/how-to-re-integratedigital-into-diplomacy/HowtoReintegrate\# DigitalintoDiplomacy.

Movanita, A. N. K. (2016). Minister Said The Important Role of Social M edia For Diplomacy. (Kata M enlu soal Peran Penting Media Sosial untuk Kelancaran Diplomasi). From http:// nasional.kompas.com/read/2016/10/08/11473291/ kata.menlu.soal.peran.penting.media.sosial.untuk.kelancaran.diplomasi retrieved October 5, 2016.

Natarajan, K. (2014). Digital Public Diplomacy and a Strategic Narrative for India. Journal Strategic Analysis. Vol. 38. Issue 1. pp. 91-106.

Potter, E. H. (2002). Cyber-diplomacy: Managing Foreign Policy in the Twenty-First Century. Montreal: McGill-Queen's University Press.

Parameswaran, P. (2015). Indonesia's Cyber Challenge under Jokowi. From http://thediplomat.com/2015/01/indonesiascyber-challenge-under-jokowi/ retrieved October 2, 2016. (2018). What's Next for Indonesia's New Cyber Agency? From https://thediplomat.com/2018/01/whats-next-forindonesias-new-cyber-agency/.

Ramadhan, A. (2018). Towards Indonesian Digital Diplomacy. From https://ahmad ramadhan58.wordpress.com/2018/03/30/ towards-indonesian-digital-diplomacy/.

Raeburn, S. (2013, November 25). Foreign Policy M eets Social Media: Indonesia Spy Row Ushers in Digital Diplomacy. From http://www.thedrum.com/opinion/2013/11/25/ foreign-policymeets-social-media-ind onesia-row-ushers-digital-diplomacy.

Titifanue, J., Tarai, J., Kant, R., \& Finau, G. (2016). From Social Networking to Activism: The Role of Social M edia in the Free West Papua Campaign. Pacific studies. November 2016.

Verrekia, B. (2017). Digital Diplomacy and Its Effect on International Relations. Independent Study Project. From http:// digitalcollections.sit.edu/isp_collection/2596.

Watts, C. (2016). What Should We Make of The Islamic State's Ramadan Wave of Violence. Foreign Policy Research Institute. From http://www.fpri.org/2016/07/make-islamic-statesramadan-wave-violence/ retrieved September 7, 2016.

Yosephine, L. (2016). Sawy Social Media Diplomacy A Standard in Digital Era. http://www.thejakartapost.com/news/2016/04/01/ sawy-social-media-diplomacy-a-standard-in-digital-era.html. retrieved October 1, 2016. 